\title{
KEARIFAN LOKAL RUMAH BETANG SUKU DAYAK DESA DALAM PERSPEKTIF NILAI FILOSOFI HIDUP (Studi Etnografi: Suku Dayak Desa, Desa Ensaid Panjang Kecamatan Kelam Permai)
}

\author{
Eliana Yunitha Seran, Mardawani \\ STKIP Persada Khatulistiwa, Program Studi PGSD, Program Studi Pendidikan Pancasila dan \\ Kewarganegaraan, Sintang \\ E-mail: elianatapoona@gmail.com, mardawani113@yahoo.co.id
}

\begin{abstract}
This research attempts to review and analyze the value of life philosophy contained in the life of the Dayak Desa relatedwith local wisdom of dayak which is retained until now. This Research located in ensaid Panjang village, district of Kelam Permai, Sintang regency Kalimantan Barat. This research methodology adopted descriptive qualitative which obtain information from residents who inhabiting long house through: Pon rumah, juru peliara, the leader in that village and people who live in that long house. The results of the research found: 1). The villagers' life of Dayak desa tribe living together in long house has been found the value of family spirit, the value of companionship and the value of simplicity and love nature, 2). The education value contained in lifestyle and the philosophy of Dayak Desa tribe in that long house is the character education through the example of the elders who have inherited and implanted vertically to his son, 3). The local wisdom of Dayak desa tribe in long Ensaid long house can be seen from two dimensions these are knowledge and the act of being patterned in an heredity manner or form the tradition across the generations.
\end{abstract}

Keyword: Local Wisdom, Life Philosophy Value, Village Dayak Tribe 


\begin{abstract}
Abstrak
Penelitian ini bertujuan untuk mengkaji dan menganalisis nilai filosofi hidup yang terdapat dalam kehidupan Suku Dayak Desa terkait dengan kearifan lokal Suku Dayak yang masih dipertahankan sampai saat ini. Lokasi penelitian yaitu Desa Ensaid Panjang yang berada di Kecamatan Kelam Permai Kabupaten Sintang Kalimantan Barat. Metode penelitian menggunakan pendekatan deskriptif-kualitatif, menggali informasi dari warga yang mendiami rumah betang melalui: Pon Rumah, Juru Peliara, Ketua adat/Dusun, dan masyarat yang menghuni rumah betang Ensaid Panjang. Hasil penelitian yang ditemukan yaitu:1) Nilai filosofi hidup Suku Dayak Desa yang hidup bersama di rumah betang Ensaid Panjang ditemukan beberapa nilai yaitu nilai kekeluargaan, nilai kebersamaan dan nilai kesederhanaan serta cinta alam . 2) Nilai pendidikan yang terkandung dalam pola hidup dan filosofi hidup masyarakat Dayak Desa di rumah Betang Ensaid Panjang adalah pendidikan karakter lewat proses keteladanan hidup para orangtua yang diwariskan dan ditanamkan secara vertikal kepada anaknya, 3) Kearifan lokal Suku Dayak Desa di rumah Betang Ensaid Panjang dapat dilihat dari dua dimensi, yaitu pengetahuan dan tindakan yang berpola secara turun-temurun atau lintas generasi membentuk tradisi.
\end{abstract}

Kata kunci: Kearifan Lokal, Nilai Filosofi Hidup, Suku Dayak Desa 


\section{A. Pendahuluan}

Sejalan dengan visi dan misi pelestarian kebudayaan dari Kementrian Pendidikan dan Kebudayaan Nasional, adapun pembangunan kebudayaan diprioritaskan pada Peningkatan Kesadaran dan Pemahaman Jati Diri dan Karakter Bangsa; Peningkatan Apresiasi Masyarakat Terhadap Keragaman, serta Kreatifitas Nilai Budaya, tradisi, kepercayaan,sejarah, Seni, dan Film; Peningkatan Kualitas Pengelolaan, Pelindungan, Pengembangan, dan Pemanfaatan Warisan Budaya; Peningkatan Internalisasi dan Diplomasi Budaya; Pengembangan Sumberdaya Budaya; Peningkatan Sarana dan Prasarana Kebudayaan. Bahkan, pada era global sekarang, transformasi itu berjalan dengan sangat cepat yang kemudian mengantarkan masyarakat Indonesia pada masyarakat berbasis pengetahuan tanpa menghilangkan jati diri bangsa.

Tujuan dan visi misi ini relevan dengan adanya upaya pelestarian budaya lokal yang terus digalakkan untuk meningkatkan dan memperkuat budaya nasional. Banyak sekali dewasa ini kita jumpai generasi muda yang ada di Kabupaten Sintang baik siswa maupun mahasiswa yang saat ditanyai tidak memahami dengan baik budayabudaya yang melekat pada identitasnya. Mereka hanya memahami bahwa mereka suku Dayak tetapi tidak memahami dengan baik unsur-unsur yang menjadi pengiring pada identitasnya sebagai anak Suku Dayak. Hal ini jika tidak mendapat penangangan maka akan mengakibatkan hilangnya nilai budaya cinta budaya lokal apalagi ditambah dengan maraknya arus globalisasi di dunia modern ini.

Selain itu kurangnya upaya yang dilakukan di bangku sekolah pada pengenalan budaya lokal, pada mata pelajaran IPS dan PPKn yang terkesan kaku tanpa pengenalan masyarakat sebagai laboratorium IPS. IPS sebagai salah satu mata pelajaran hanya disampaikan pada level pengetahuan tanpa sampai pada upaya penanaman nilai serta sikap dan keterampilan untuk cakap dalam kehidupan sosial. Hal ini perlu untuk menjadi perhatian bersama, mengingat bahwa pembelajaran IPS menjadi kehilangan roh dan jiwa nya jika anak tidak diperkenalkan pada alam sekitar.

Prototipe pembelajaran budaya lokal suku Dayak di Kabupaten Sintang salah satunya adalah Subsuku Dayak 
Desa di Ensaid Panjang, Kecamatan Kelam Permai, Kabupaten Sintang, Kalimantan Barat, masih mempertahankan tradisi turun-temurun tinggal di rumah besar atau rumah betang. Berlatar belakang Gunung Rentap rumah Betang Ensaid Panjang berdiri kokoh. Arsitekturnya sederhana, coraknya menampilkan nuansa yang dengan alam. Hampir semua bahan bangunannya berasal dari kayu yang tersedia di alamnya. Rumah betang yang ditempati oleh 100 orang dari 22 keluarga itu berukuran 118 meter x 17 meter. Rumah panggung itu memiliki tinggi sekitar 12 meter, dengan jarak lantai kayu dari tanah sekitar dua meter.

Adanya nilai kearifan lokal dan nilai kebersamaan serta gotong royal dalam kehidupan komunal inilah yang menjadi potret filosofis kehidupan Suku Dayak Desa di Kabupaten Sintang. Nilai local wisdom ini memberi gambaran bagaimana kehidupan sesungguhnya masyarakat Suku Dayak Desa yang hidup dengan damai dalam kebersamaan sebagai ciri utama bangsa Indonesia yaitu semangat kekeluargaan dan gotong royong.

\section{B. Metode}

Metode yang digunakan dalam penelitian ini adalah metode deskriptif dengan bentuk penelitian studi etnografi. Metode ini dipilih berdasarkan permasalahan yang ditemukan yang berupa kajian masyarakat, ras atau sebuah kelompok kebudayaan. Etnografi berarti sebuah ilmu yang menjelaskan cara hidup manusia. Dalam penelitian ini pengumpulan data dilakukan secara sistematis dan deskriptif. Analisis data dilakukan dengan tujuan untuk mengembangkan teori prilaku kultural. Dalam penelitian etnografi, peneliti secara aktual hidup atau menjadi bagian dari setting budaya dalam tatanan untuk mengumpulkan data secara sistematis dan holistik.

Dalam rangka membantu mekanisme kerja peneliti maka teknik pengumpulan data yang digunakan adalah teknik observasi langsung, teknik komunikasi langsung dan teknik dokumenter. Alat pengumpul data berupa panduan observasi, panduan wawancara dan angket. Observasi dan wawancara adalah cara pengumpulan data yang umum dilakukan dalam penelitian etnografi. Keduanya dilakukan bersamaan di dalam setting alamiah 'yang diteliti', dan saling melengkapi untuk mendapatkan gambaran tentang 'yang lain'. 
Observasi

dan

wawancara

menggunakan peneliti sebagai alat pengumpul data-melalui indera (penglihatan, pendengaran, dan perasa), dan kemampuan untuk berkomunikasi.

Observasi dan wawancara dalam etnografi tidak bisa dilepaskan dari partisipasi, yang berarti peneliti hampir sepenuhnya 'menenggelamkan diri' di dalam kehidupan bersama masyarakat yang diteliti. Kegiatan ini kemudian dikenal sebagai pengamatan partisipatif (participant observation).

Teknik analisis data yang digunakan adalah deskriptif kualitatif memanfaatkan persentase hanya merupakan langkah awal dari proses analisis data (Arikunto, 2010) Dalam proses analisis data kualitatif terdiri dari empat alur kegiatan yang terjadi secara bersamaan, yaitu catatan lapangan, pengumpulan informasi, penyajian informasi, dan penarikan kesimpulan (Arikunto, 2010). Pengumpulan data dilakukan sendiri oleh peneliti, sejalan dengan pendapat Bungin, 2010 "Etnografi menggunakan peneliti sebagai alat pengumpul data - melalui indera penglihatan, pendengaran, dan perasa".

Proses analisis data dilakukan secara simultan yang mencakup klarifikasi, interpretasi dan analisis data.

Analisis data dilakukan secara deskriptif (descriptive analysis). Setelah melewati proses analisis data yang dilakukan secara simultan, kemudian ditarik kesimpulan hasil penelitian.

\section{Pembahasan Dan Hasil}

Berdasarkan hasil penelitian ditemukan beberapa nilai filosofi hidup pada kearifan lokal rumah betang Ensaid Panjang, yakni sebagai berikut:

a. Pertahanan hidup (eksistensi); menjadi simbol yang kukuh dari kehidupan komunal masyarakat Dayak.

1. Mata Pencaharian utama

Sebagian besar masyarakat Ensaid Panjang bekerja sebagai penyadap atau penoreh karet yang milik sendiri atau bekerja sebagai pekerja pada kebun karet milik orang lain dengan sistem bagi hasil. Pekerjaan sebagai penyadap karet ini telah dilakukan secara turun temurun yang dilakukan dipagi hari sedangkan untuk mengisi waktu kosong lainnya masyarakat Ensaid Panjang melakukan pekerjaan tambahan yang dapat menghasilkan uang untuk menyambung kehidupan dan menyekolahkan anak-anak.

Perkebunan karet hampir dimiliki oleh semua masyarakat di Ensaid 
Panjang dikarenakan sistem penanamannya dan kepemilikannya dilakukan pada saat setelah musim panen pada ladang milik pribadi masing-masing keluarga. Setelah membuka lahan tanah dan hutan untuk di tanam dengan padi maka sudah menjadi tradisi maka lahan yang telah terbuka itu akan ditanami dengan tanaman karet sehingga dengan demikian maka tanah dan kebun tersebut sudah sah menjadi milik orang tersebut.

Hal inilah yang menjadi tanda kearifan lokal pada masyarakat Dayak Desa di rumah betang Ensaid Panjang untuk terus melestarikan hutan maka dilakukan regulasi dan reboisasi untuk terus menjadi hutan sebagai sumber kehidupan.

2. Mata Pencaharian tambahan

Selain pekerjaan sebagai petani yang mengerjakan lahan di ladang maka pekerjaan tambahan yang dilakukan oleh masyarakat Ensaid menjadi. buruh bangunan, buruh di perusahaan sawit, memahat, dan menenun bagi ibuibu.

Pekerjaan sebagai penenun ini dilakukan oleh kurang lebih sekitar 40 orang wanita yang berusia 9-80 tahun di Rumah Betang Ensaid panjang. Pekerjaan ini dilakukan karena harga kain tenun untuk saat ini masih sangat menjanjikan, adapun harga kain yang kecil seperti syal dihargai sebesar Rp. 50.000 dan kain panjang di hargai sebesar Rp. 300.000 - 600.000. Dan proses pengerjaan kain tenun untuk kain yang berukuran besar akan memakan waktu sekitar 1-2 bulan bahkan bisa sampai 4 bulan.

Para pengerajin kain tenun di Ensaid Panjang Saat ini kerap kali menerima pesanan. Proses pengerjaan kain sangatlah rumit menggunakan alat tenun dari kayu. Warna-warni kain tenun yang dihasilkan pun bervasriasi berkisar pada warna hitam, merah dan kuning dengan menggunakan pewarna alami misalnya warna merah dari buah mengkudu, kuning dari kunyit dan warna-warna lain yang diambil dari daun marak dan tarum.

Adapun tahapan dalam menenun terdiri dari ngulayan, menyusun benang, negi (proses sebelum mengikat), mulai mengikat, dan memberi warna menggunakan benang atau cat warna.Terdapat empat macam tenun ikat berdasarkan tingkat kesulitannya yaitu tenun kebat, sidan, songket dan plin slam. Tenun kebat memiliki ciri motof berbentuk bunga, manusia serta naga. Kain tenun sidan bermotif bunga dan orang. 
b. Semangat persatuan dan kebersamaan.

Dengan mendiami rumah betang dan menjalani segala proses kehidupan di tempat tersebut, masyarakat Dayak menunjukkan bahwa mereka juga memiliki naluri untuk selalu hidup bersama dan berdampingan dengan warga masyarakat lainnya.

Terdapat beberapa nilai yang melekat dalam kehidupan masyarakat Dayak Desa di rumah betang Ensaid Panjang yaitu :

1). Nilai kebersamaan dalam gotong royong

Warga rumah betang Ensaid Panjang memiliki beragam tradisi dan budaya di dalam kehidupannya. Kehidupan sehari-hari di rumah betang diwarnai dengan persaudaraan yang sangat kuat. Orang sekampung hidup dengan rukun dan bersatu dalam hal kecil maupun dalam hal besar. Jika salah satu orang berburu dan mendapatkan kijang, babi atau binatang lainnya, ia mesti membagikannya ke para tetangga. Saat berladang, dalam setiap rangkaian kegiatannya dilakukan dengan gotong royong atau biasa disebut dengan beduruk. Setiap warga saling membantu apabila ada keluarga yang mengalami musibah atau mengadakan pesta, misalnya pada acara gawai dayak dimana semua warganya saling bahu membahu untuk memberikan yang terbaik.

Nilai gotong kebersamaan yang saat erat pada masyarakat rumah betang Ensaid Panjang ini sudah menjadi sebuah tradisi yang turun temurun, rumah betang Ensaid panjang yang dihuni oleh 100 orang ini memang memiliki hubungan darah sehingga nilai kekeluargaan dan kebersamaan seperasaan dan sepenangungan serta saling memerlukan mewarnai kehidupannya.

Nilai utama yang menonjol dalam kehidupan di rumah Betang adalah nilai kebersamaan (komunalisme) di antara para warga yang menghuninya, terlepas dari perbedaan-perbedaan yang mereka miliki. Dari sini kita mengetahui bahwa suku Dayak adalah suku yang menghargai suatu perbedaan, mereka menghargai perbedaan etnik, agama ataupun latar belakang sosial. Budaya Rumah Betang adalah budaya yang menjunjung nilai kebersamaan, persamaan hak, saling menghormati, dan tenggang rasa. Rasa kebersamaan dan persaudaraan tampak setiap ada permasalahan yang menimpa salah satu penghuni. Jika salah satu anggota keluarga ada yang meninggal dunia 
maka masa berkabung mutlak masyarakat biasanya mengadakan diberlakukan selama satu minggu bagi semua penghuni dengan tidak menggunakan perhiasan, tidak berisik, tidak minum tuak dan dilarang menghidupkan peralatan elektronik.

Konsep kerukunan dan kesetaraan perlu terus dipertahankan dan dipelihara karena konsep-konsep tersebut esensial bagi identitas Dayak. Sekarang, nilai individualistik telah mulai merasuk dalam jiwa masyarakat Dayak. Hal itulah yang membuat mereka lebih memilih untuk tinggal di rumah individual dibanding di Rumah Betang. Hal ini disebabkan karena proses globalisasi dan modernisasi yang masuk dalam kehidupan masyarakat Dayak, globalisasi membuat nilai kerukunan yang tadinya menjadi ciri masyarakat Dayak menjadi pudar dan tergantikan oleh nilai individualistik. Padahal konsep kerukunan dan tinggal bersama di rumah Betang dan menghindarkan ketamakan adalah nilai budaya yang esensial bagi masyarakat Dayak, dan oleh karenanya nilai tersebut seharusnya dipelihara dan dilestarikan.

2). Nilai Budaya yang diwariskan lewat acara gawai Dayak

Bulan April-Juli merupakan bulan jedah atau istirahat berladang bagi masyarakat desa ini. Saat itulah Gawai. Mereka saling bertandang ke kampung lain, bersilahturahmi untuk memperkuat tali persahabatan.

Pada masyarakat adat Dayak Desa istilah pe'gawai berbeda dengan gawai. Pe'gawai merupakan pesta atau hajatan seperti halnya upacara adat tanam bunga, gunting rambut, ngansah gigi, tutup tahun dan lainnya, sedangkan gawai merupakan ajang penyelesaian perkara di masyarakat, seperti bejerehbebantah, bej ereh- sabung adat, dan lain-lain. Akan tetapi, ketika mengadakan acara pesta besar, istilah Gawai Dayak lebih umum dan dikenal masyarakat.

Biasanya pe'gawai di laksanakan selepas musim panen, seperti bulan April-Juli. Namun demikian, pe'gawai bisa juga dilaksanakan pada waktu lain. Selepas musim panen masyarakat selalu mengadakan pegawai yang biasanya dinamakan dengan gawai tutup tahun . Bersamaan dengan itu juga diadakan berbagai hajatan seperti upacara adat tanam bunga, gunting rambut, dan lainnya. Pelaksanaan pe'gawai setelah musim panen dikarenakan pada saat itu masyarakat tidak terlalu sibuk bekerja, dan masa itu merupakan masa istirahat berladang. 
Setiap kali ada pe'gawai , kampung menjadi ramai. Dari berbagai kampung datang dan semua Inti dari pe'gawai adalah silahturahmi. Masyarakat bisa ngabang atau berkunjung ke satu kampung ke kampung lainnya untuk bertemu gaok (kangen) dan mempererat tali persahabatan. Sedangkan gawai tutup tahun (nyelapat taun) diadakan untuk merayakan atau selamatan atas hasil panen yang diperoleh. Ada anggap di masyarakat, bahwa sebelum mereka belum mengadakan gawai tutup tahun, mereka belum bisa berladang. Saat gawai tutup tahun masyarakat menyuguhkan makanan kepada kerabat yang berkunjung ke rumah panjang, itu dimaksudkan agar hasil panen yang mereka dapatkan juga bisa dirasakan orang lain.

Adapun pe'gawai yang biasa dilakukan masyarakat pada saat gawai tutup tahun antara lain sebagai berikut : Gunting rambut, diselenggarakan keluarga yang memiliki anak kecil. Gawai ini bertujuan agar anak yang digunting rambutnya kelak hidupnya berkat, selamat dan diberikan kemudahan rejeki.

Tanam Bunga, diadakan untuk menyembuhkan anak yang sakit. Tanam bunga dilakukan bersama semanang (dukun), agar sakit si anak lekas sembuh. Patah Bunga, diselenggarakan untuk memenuhi syarat akhir dari tanam bunga, agar anak tersebut sembuh dari sakit. Asah Gigi, diselenggarakan untuk menandakan remaja putra/putri tumbuh dewasa agar bisa be rumah tangga. Bawa Bayi Mandi di Sungai, Gawai ini diselenggarakan agar bayi yang dimandikan tersebut kelak diberkati dan dimudahkan rejekinya.

Masyarakat Suku Dayak Desa di Ensaid Panjang memiliki kekayaan seni budaya tutur atau tradisi lisan. Seni budaya tutur ini umumnya berupa kisah atau ungkapan perihal tertentu, seperti kisah tentang asal mula kehidupan, keseharian, mitos, atau hanya berupa ungkapan yang berfungsi sebagai sindiran, pujian, nasehat, atau bahkan untuk memanjatkan doa. Oleh karenanya disamping untuk menghibur, seni budaya tutur ini juga ada yang bersifat semireligius. Beberapa Seni Budaya Tutur yang dimiliki masyarakat Ensaid Panjang diantaranya adalah Bekana, Bekanduk, Bedarak, Semayan, Bejereh dan Bebantah.

c. Melindungi eksistensi kelompok dari serangan atau ancaman 
Mereka mencintai kedamaian dalam komunitas yang harmonis sehingga mereka berusaha keras untuk mempertahankan tradisi rumah betang ini. Rumah Betang Ensaid Panjang berbentuk panggung maka dari itu tentu ada tangga untuk menaiki rumah betang ini. Tangga rumah betang sengaja dibuat tinggi. Ratusan tahun lalu, tinggi tangga bisa mencapai 8 meter hal ini ditujukan untuk melindungi penghuni dari serangan musuh dan tangga tersebut terbuat dari kayu yang utuh sehingga memerlukan tenaga yang kuat untuk menaikinya. Menurut Rikardus Simbai (Pengurus Desa) setempat pada jaman dahulu dikarenakan tingginya tangga rumah betang maka jika di lempar dengan tombak pun tidak sampai keatas. Jika sudah malam tangganya ditarik, pintunya ditutup. Supaya musuh-musuh tidak masuk.

Pada saat itu adalah musim kayau yang merupakan sebuah tradisi berburu kepala manusia saat perang suku. Ini lazim terjadi di zaman dahulu, saat antar suku kerap saling menyerang. Jika bisa mendapatkan kepala manusia artinya orang tersebut dianggap kesatria. Kepala itu lantas dihadiahkan kepada keluarga sebagai bukti kemenangan dan dijadikan persembahan saat berlangsungnya upacara adat.

Ditambahkan lagi alasan pembangunan rumah betang yang tinggi untuk alasan keamanan. Baik dari sesama manusia dalam perang antar suku maupun dari hewan buas karena pada masa itu kehidupan masyarakat Dayak masih sangat berdampingan dengan hutan-hutan yang lebat sehingga masih banyak sekali binatang-binatang buas.

Rumah Betang Ensaid Panjang adalah satu dari sedikit rumah betang yang masih bertahan di Kalimantan Barat dan satu-satunya yang masih berdiri di Kabupaten Sintang. Giring Melabo adalah peneliti di Institute Dayakologi yang pernah melakukan penelitian tentang Rumah Betang. Ia menemukan, jumlah rumah betang di penjuru Kalimantan Barat kini tak lebih dari 27 buah yang masih ada sampai saat ini. Sementara pada jaman dahulu terdapat ribuan rumah betang sebagai sebuah bentuk kehidupan masyarakat Dayak. Salah satu penyebab hilangnya kehidupan dan budaya tinggal di rumah betang adalah penggusuran di era 1960an. Pada saat itu pemerintah beralasan bahwa kurang sehat bagi orang Dayak karena hidup berhimpitan sehingga 
menimbulkan banyak dampak negatif. Selain itu juga dianggap menumbuhkan nilai-nilai komunalisme yang bisa berkembang ke komunisme karena pada saat itu paham komunisme merupakan paham yang berusaha merongrong ideologi negara yaitu Pancasila.

Penggusuran ini sedikit banyak mengubah tatanan kehidupan masyarakat Dayak yang secara turun temurun terbiasa tinggal di rumah betang. Masyrakat banyak yang kemudian membangun rumah tunggal, tak lagi tinggal bersama keluarga besarnya. Hal ini kemudian dirasakan menggerus nilai solidaritas, nilai kebersamaan masyarakat Dayak mulai terkikis, individualisme sedikit banyak mulai merambahi kehidupan masyarakat Dayak secara keseluruhan.

\section{d. Membangun solidaritas \\ persaudaraan, rasa sepenanggungan dan kebersamaan.}

Kesadaran setiap individu untuk menyelaraskan setiap kepentingannya dengan kepentingan bersama. Kesadaran tersebut dilandasi oleh alam pikiran religio-magis, yang menganggap bahwa setiap warga mempunyai nilai dan kedudukan serta hak hidup yang sama dalam lingkungan masyarakatnya.
Rumah Betang Ensaid Panjang menjadi salah satu saksi sejarah yang hingga kini masih berdiri kokoh dengan para penghuninya yang setia. Berkat keunikannya inilah, Ensaid Panjang sering dikunjungi wisatawan untuk ikut menikmati perpaduan hidup zaman modern tetapi dibalut oleh kesederhanaan dan kental dengan aroma kearifan lokalnya.

Upaya untuk terus mempertahankan tradisi adalah lewat kebiasan berkumpul bersama di ruai (ruang utama) pada rumah betang, pada orangtua sambil menenun, menganyam ataupun memahat memberikan dan menurunkan nilai-nilai hidup kepada anak-anaknya diantaranya adalah nilai sopan santun dan tata krama kepada orangtua serta kepada tamu-tamu yang mampir di rumah betang Ensaid Panjang.

Selain dengan kebiasaan tersebut diatas maka beberapa upaya untuk terus mempertahakan dan mewariskan nilainilai budaya pada masyarakat Dayak Desa di rumah betang Ensaid panjang juga melalui beberapa kegiatan yang dilakukan bersama-sama diantaranya adalah gawai dayak, berladang, dan panen padi serta beberapa kegiatan keagamaan. Lewat kegiatan-kegiatan ini maka generasi muda diajarkan lewat 
sikap dan perilaku bahwa hidup saling memerlukan dan tak ada manusia yang dapat memenuhi kebutuhannya sendiri. Untuk itu maka manusia perlu terus menanamkan dalam diri tentang sikap saling menghargai dan menghormati satu sama lain.

Dalam memenuhi kebutuhan hidupnya manusia pun tak dapat terlepas dari bantuan orang lain, masyarakat Dayak Desa sangat meyakini itu. Sistem pengerjaan ladang mulai dari membuka lahan sampai panen semuanya dikerjakan bersama dalam kegiatan gotong royong yang tak pernah diperhitungkan dengan besarnya angka rupiah. Ini menunjukkan bahwa masyarakat Dayak Desa unggul dalam rasa solidaritas dan kebersamaan, ini merupakan cerminan sikap bangsa Indonesia yang perlu dipertahankan oleh semua pihak.

\section{Simpulan}

Berdasarkan hasil dan pembahasan penelitian yang telah diperoleh peneliti, dapat disimpulkan sebagai berikut:

1. Nilai filosofi hidup Suku Dayak Desa yang hidup bersama di rumah betang Ensaid Panjang berdasarkan pada hasil wawancara, observasi dan catatan lapangan maka ditemukan beberapa nilai yaitu nilai kekeluargaan, nilai kebersamaan dan nilai sederhana serta cinta alam . Masyarakat Dayak Desa yang mendiami rumah betang yang mendiami 28 bilik dalam rumah betang dan berjumlah kurang lebih 100 orang ini meski terdiri dari berbagai suku mereka adalah satu keluarga yang merasa seperasaan, sepenanggungan dan saling memerlukan satu sama lain. Nilai kebersamaan dalam masyarakat Dayak Desa di rumah betang Ensaid Panjang terlihat, terjaga dan terus dilestarikan lewat beberapa kegiatan yaitu gotong royong dalam pengerjaan dan pada saat panen di ladang, kegiatan gawai Dayak dan kegiatan keagamaan lainnya. Sedangkan nilai kesederhaan dan cinta alam masyarakat Dayak Desa di rumah Betang Ensaid Panjang tumbuh dan berkembang lewat kegiatan kehidupan sehari-hari untuk pemenuhan kebuituhan hidup misalnya berladang, pengerjaan kebun, dimana masyarakat Dayak Desa memiliki pandangan akan pelestarian alam dengan cara dan metode yang sederhana yaitu menanami kembali lahan yang telah di buka dengan tanaman karet sehingga hutan dan 
alam selalu terjaga. Nilai pendidikan yang terkandung dalam pola hidup dan filosofi hidup masyarakat Dayak Desa di rumah Betang Ensaid Panjang adalah pendidikan karakter lewat proses keteladanan hidup para orangtua yang diwariskan dan ditanamkan secara vertikal kepada anaknya. Lewat nilai kekeluargaan dan kebersamaan ditanamkan lewat pendidikan karakter pada anak cucu mereka bahwa semua orang yang mendiami rumah betang adalah satu keluarga bahkan tamu pun adalah keluarga yang harus di hormati dan dihargai dengan baik lewat tutur kata dan peragaan perbuatan yang baik pula. Nilai peduli alam dan cinta alam adalah sebuah nilai pendidikan karakter yang dewasa ini banyak diajarkan di sekolahsekolah agar manusia kembali pada sejatinya kehidupannya bersatu dengan alam sehingga alam akan terus memberikan kehidupan yang tak pernah berhenti kepada manusia, maka manusia harus berbuat baik pada alam.

2. Keterkaitan nilai filosofi dan nilai pendidikan yang terkandung dalam kehidupan Suku Dayak Desa terkait dengan kearifan lokal Suku Dayak yang mampu bertahan sampai hari

ini. Kearifan lokal Suku Dayak Desa di rumah Betang Ensaid Panjang dapat dilihat dari dua dimensi, yaitu pengetahuan dan tindakan yang berpola, dan lazim diwariskan secara turun-temurun atau lintas generasi membentuk tradisi. Ditemukannya pengetahuan yang terus diturunkan dalam hal memanfaatkan alam untuk kelangsungan kehidupan, Suku Dayak Desa di rumah Betang Ensaid Panjang memiliki pengetahuan dan keterampilan yang baik soal menganyam peralatan untuk berladang, membuat peralatan berburu, dan memanfaat warna warni tumbuhan alam untuk kegiatan menenun.

3. Kearifan lokal Suku Dayak Desa di rumah betang Ensaid Panjang dapat dipilah menjadi kearifan sosial dan kearifan ekologi. Kearifan sosial dipedomani agar menjadi makhluk sosial yang arif dan bijaksana. Hal ini tercermin dalam adanya nilainilai filosofi hidup yang diwariskan dan ditanamkan secara vertikal dari orangtua kepada anaknya lewat nilai-nilai keteladanan hidup seharihari misalnya saling menghormati antara anak dan orangtua, antar anak dan sesamanya serta nilai peduli alam sekitar. Nilai peduli 


\begin{abstract}
alam sekitar diwariskan dengan cara Suku Dayak Desa terbiasa secara turun temurun membawa serta anak-anak mereka untuk terlibat langsung dalam mengerjakan ladang dan kebun milik mereka. Kearifan ekologi merupakan pedoman manusia agar arif dalam berinteraksi dengan lingkungan alam biofisik (sekala) dan supernatural (niskala). Dengan demikian kearifan lokal dapat dijadikan sarana untuk membangun dan megembangkan karakter masyarakat.
\end{abstract}

\section{Daftar Pustaka}

Abubakar, HM. 2016. Huma Betang Dan Aktualisasi Nilai Kearifan Lokal Dalam Budaya Dayak. Jurnal Humanika Vol. 1, No. 2, Juli - Desember 2016.

Admaja, N.B. 2008. Kearifan Lokal: mendekatkan kesenjangangan teks ideal dan teks sosial melalui pikiran menyintesis dan multiperspektifisme.

Arikunto, Suharsimi. 2010. Prosedur Penelitian: suatu pendekatan Praktek: Jakart: Rineka Cipta

Darmawanus. 2009. Kondisi Suku dayak Di Tengah Arus Globalisasi. (Online). (http://rdarmawanus.blogspot.co.i d/2009/12/kondisi-suku-dayak-di- tengah-arus.html, diakses $5 \mathrm{Mei}$ 2016).

Kifli, Gontom C. 2007. Strategi Komunikasi Pembangunan Pertanian Pada Komunitas Dayak Di Kalimantan Barat. Jurnal Forum Penelitian Agro Ekonomi. Volume 25 No. 2, Desember 2007: 117-125.

Mardawani dan Triana, D. (2016). Peranan Moral Quontient Suku Dayak Dalam Upaya Pemenuhan Kebutuhan Pokok (Studi Fenomenologis Di Desa Bukit Segaloh Kecamatan Kayan Hilir Kabupaten Sintang Kalimantan Barat). Jurnal Sosio Didaktika.Vol. 3 No 1 Juni 2016: 62-69. (2017). Pengembangan Karakter Kebangsaan Berbasis Kearifan Lokal Sebagai Alternatif Pada Pendidikan Informal Di Kabupaten Sintang. Jurnal Pekan. Vol. 2 No 2, November 2017: 8589.

Miles, Mattew B dan Hubermen, Michael. 1992. Analisa Data Kualitatif: Buku Sumber Tentang Metode Baru, Terjemahan Tjetjep Rohendy (2007), Jakarta: UI Press.

Moleong, Lexy.J. 1990. Metode Penelitian Kualitatif. Bandung: Remaja Rosda Karya. 